\title{
Cowpea Crude Protein as Affected by Cropping System, Site and Nitrogen Fertilization
}

\author{
E. T. Sebetha ${ }^{1}$, A. T. Modi ${ }^{1} \&$ L. G. Owoeye ${ }^{2}$ \\ ${ }^{1}$ Crop Science, School of Agriculture, Earth and Environmental Sciences, University of KwaZulu-Natal, \\ Scottsville, South Africa \\ ${ }^{2}$ Agricultural Research Council-Institute for Industrial Crops, Rustenburg, South Africa \\ Correspondence: E. T. Sebetha, Crop Science, School of Agriculture, Earth and Environmental Sciences, \\ University of KwaZulu-Natal, Private Bag x 01, Scottsville 3209, South Africa. E-mail: \\ erick.sebetha@nwu.ac.za
}

\author{
Received: September 11, 2014 Accepted: November 2, $2014 \quad$ Online Published: December 15, 2014 \\ doi:10.5539/jas.v7n1p224 URL: http://dx.doi.org/10.5539/jas.v7n1p224
}

\begin{abstract}
High protein content in cowpea (Vigna unguiculata (L.) Walp.) is considered as major advantage for its use in nutritional components. In this way, an experiment was conducted to investigate the effect of cropping system, site, and nitrogen fertilization on cowpea crude protein. The study comprised of three cropping systems (Maize-cowpea rotation, monocropping cowpea and intercropped cowpea), three sites (Potchefstroom, Taung, and Rustenburg, South Africa) and two rates of nitrogen fertilizers applied in $\mathrm{kg} \mathrm{ha}^{-1}$ at each site $(0$ and 20 at Potchefstroom, 0 and 17 at Rustenburg, 0 and 23 at Taung). Moreover, a factorial experiment randomized in complete block design with three replications was conducted during 2011/12 and 2012/13 planting seasons. The protein content was determined from green leaves harvested before flowering, immature green pods and seeds during reproductive stage and maturity. Results showed that cropping system had significant effect on cowpea leaf protein content $(\mathrm{P}<0.05)$. Intercropped cowpea significantly gave higher leaf protein $(26.7 \%$ more $)$ content than rotational cowpea. Cowpea planted at Taung had significantly higher leaf protein $(30.1 \%$ more $)$ content as compared to cowpea planted at other sites. Application of nitrogen fertilizer contributed to higher protein content of immature pods. Moreover, cowpea protein content differs among the different locations due to different soil types and climatic conditions.
\end{abstract}

Keywords: cropping system, immature pods, leaf, protein content, seed

\section{Introduction}

Cowpea (Vigna unguiculata (L.) Walp.) plant parts such as leaves, pods and seeds are eaten by people and are rich in protein. Since cowpea is a major source of protein in diet of many people in sub-Saharan Africa, any effort made to increase the level of protein in the seed would improve the quality of the diet of the population (Vadivel \& Pugalenthi, 2010). Some people eat both fresh pods and leaves and the dried seeds are popular ingredients in various dishes (El Naim et al., 2012). The seeds can also be cooked with meat, tomatoes and onions into a thick soup, eaten with pancake and bread. The nutritional profile of cowpea grain is similar to that of other pulses with a relatively low fat content and a total protein content that is two to four higher than cereal and tuber crops (Timko \& Singh, 2008). Total seed protein content ranges from $23 \%$ to $32 \%$ of seed weight (Cruz et al., 2014). It is estimated that cowpea supplies about $40 \%$ of the daily protein requirements to most of the people in Nigeria (Kamai et al., 2014). Dry mature seeds are also suitable for boiling and canning. In many areas of the world, cowpea foliage is an important source of high quality hay for livestock feed (Timko \& Singh, 2008). Singh and Basu (2012) found that the protein in grain legumes like cowpea has been shown to reduce low density lipoproteins that are implicated in heart diseases.

Dugje et al. (2009) reported that some varieties are suitable for harvesting as leaves, young pods and mature seeds, each over a long period for human consumption as well as for feeding livestock. If seeds are desired, leaf harvesting should cease before the pods begin to expand, since removal of too many young leaves at once will impair seed yield (Mwanarusi et al., 2010). Santos and Boiteux (2013) reported that cowpea grain, which is valued for its high nutritive quality and short cooking time, serves as a major source of protein in the daily diets 
of the rural and urban poor; its tender leaves are eaten as spinach-like vegetable, while immature pods and seeds are also consumed as vegetable. The immature snapped pods are used in the same way as snap beans, often mixed with other foods. Elias et al. (2006) found that the protein efficiency ratio was higher in the cowpea samples than in beans. Since cowpeas have a higher nutritive value than common beans, and can be grown under many environmental conditions with higher yields, their use in human feeding should be recommended in developing areas of the world having protein in low quantity and quality (Elias et al., 2006). According to Mlynekova and Ceresnakova (2013) crude protein has previously been shown to decline with increasing crop maturities. According to Hasan et al. (2010) there was a progressive increase in the protein content of cowpea forage being influenced by the increasing level of nitrogen fertilizer. it was further indicated that crude protein yield of cowpea forage due to application of $\mathrm{N}$ fertilizer might be due to increased availability of nitrogen from the soil for the synthesis of tissue protein of the plants. According to Ali and Mohammad (2012) maize-legume intercrop could considerably increase forage quantity and quality and lessening condition for protein supplement. Hamdollah (2012) reported that, crude protein was affected by the intercropping system. It was found that environmental features such as temperature and soil fertility disturb physiological development of crops and impact forage quality (Shi et al., 2013). According to Ayan et al. (2012) no difference were found in cowpea crude protein among cultivars and years. It was indicated in their study that, location and all the interactions showed significant effect on cowpea crude protein. The influence of management system on cowpea protein content has not been widely investigated. Research has shown that selecting early generations of cowpea crops to increase yield is not an effective strategy (Ogunkanmi et al., 2006). Other methods such as bulk breeding may be more efficient in developing high-yield varieties (Ehlers, 1997). The question that has not been addressed is how intercropping, provenance and nitrogen fertilizer affect cowpea protein. In this study, the interaction effects of site, cropping system, and nitrogen fertilization on cowpea protein content were evaluated. The objective of this study therefore was to determine the effect of site, cropping system and nitrogen fertilization on edible cowpea plant parts protein content.

\section{Materials and Methods}

\subsection{Experimental Sites}

The study was conducted at three dryland sites in South Africa, namely the department of Agriculture experimental station in Taung situated at $27^{\circ} 30^{\prime} \mathrm{S}$ and $24^{\circ} 30^{\prime} \mathrm{E}$, Agriculture Research Council-Grain Crops Institute (ARC-GCI) experimental station in Potchefstroom situated at $27^{\circ} 26^{\prime} \mathrm{S}$ and $27^{\circ} 26^{\prime} \mathrm{E}$, and the Agricultural Research Council-Institute for Industrial Crops (ARC-IIC) experimental station in Rustenburg $25^{\circ} 43^{\prime} \mathrm{S}$ and $27^{\circ} 18^{\prime} \mathrm{E}$. Taung experimental site is situated in grassland savannah with annual mean rainfall of $1061 \mathrm{~mm}$ that begins in October. The ARC-GCI experimental station (Potchefstroom) has clay percentage of 34 and receives annual mean rainfall of $622.2 \mathrm{~mm}$, with daily temperature range of 9.1 to $25.2{ }^{\circ} \mathrm{C}$ during planting (Macvicar et al., 1977). The ARC-IIC experimental station (Rustenburg) has clay percentage of 49.5 and receives an annual mean rainfall of $661 \mathrm{~mm}$. Potchefstroom (ARC-GCI) has plinthic catena soil, eutrophic, red soil widespread (Pule-Meulenberg et al., 2010). The soil at Taung is described as Hutton, deep, fine sandy dominated red freely drained, eutrophic with parent material that originated from Aeolian deposits (Staff, 1999). The soil at Rustenburg (ARC-IIC) has dark, olive grey and clay soil, bristle consistency, medium granular structure (Botha et al., 1968). The soil chemical and physical properties of three sites collected before planting is as indicated in Table 1 . The weather data recorded at three sites during the course of the study is indicated on Table 2 .

Table 1. The results of soil chemical $\left(\mathrm{mg} \mathrm{kg}^{-1}\right)$ and physical properties of samples collected before planting at three sites

\begin{tabular}{llll}
\hline Site & Chemical/physical properties & $0-15 \mathrm{~cm}$ & $15-30 \mathrm{~cm}$ \\
\hline Potchefstroom & $\mathrm{pH}(\mathrm{KCl})$ & 5.84 & 5.81 \\
& $\mathrm{~N}-\mathrm{NO}_{3}$ & 2.25 & 2.90 \\
& $\mathrm{~N}-\mathrm{NH}_{4}$ & 1.25 & 0.65 \\
$\mathrm{P}($ Bray-1) & 41 & 42 \\
$\mathrm{~K}$ & 348 & 318 \\
\% Sand & 58 & 58 \\
\% Silt & 12 & 13 \\
\% Clay & 30 & 29 \\
\hline
\end{tabular}




\begin{tabular}{llll}
\hline Taung & $\mathrm{pH}(\mathrm{KCl})$ & 6.51 & 6.63 \\
& $\mathrm{~N}-\mathrm{NO}_{3}$ & 2.50 & 1.50 \\
& $\mathrm{~N}-\mathrm{NH}_{4}$ & 0.75 & 0.75 \\
& $\mathrm{P}($ Bray-1) & 7 & 7 \\
$\mathrm{~K}$ & 108 & 118 \\
& \% Sand & 91 & 91 \\
& $\%$ Silt & 1 & 1 \\
& $\%$ Clay & 8 & 8 \\
\hline Rustenburg & $\mathrm{pH}(\mathrm{KCl})$ & 4.87 & 5.07 \\
& $\mathrm{~N}-\mathrm{NO}_{3}$ & 3.25 & 1.40 \\
& $\mathrm{~N}-\mathrm{NH}_{4}$ & 0.75 & 0.50 \\
& $\mathrm{P}(\mathrm{Bray}-1)$ & 4 & 2 \\
& $\mathrm{~K}$ & 150 & 88 \\
& $\%$ Sand & 44 & 42 \\
& $\%$ Silt & 7 & 8 \\
& $\%$ Clay & 49 & 50 \\
\hline
\end{tabular}

Table 2. The mean temperature and rainfall data for Potchefstroom, Taung and Rustenburg for the duration of experimental period

\begin{tabular}{|c|c|c|c|c|c|c|c|c|c|c|}
\hline Site & Season & Climate data & Oct & Nov & Dec & Jan & Feb & Mar & Apr & May \\
\hline \multirow[t]{6}{*}{ Potch } & $2011 / 12$ & Rainfall (mm) & 35.58 & 66.29 & 75.95 & 19.05 & 33.78 & 66.29 & 4.32 & 0 \\
\hline & & $\operatorname{Max} \mathrm{T}\left({ }^{\circ} \mathrm{C}\right)$ & 28.64 & 29.45 & 28.57 & 30.42 & 29.11 & 28.72 & 25.00 & 25.00 \\
\hline & & $\operatorname{Min} \mathrm{T}\left({ }^{\circ} \mathrm{C}\right)$ & 11.19 & 13.78 & 15.81 & 16.22 & 16.30 & 13.59 & 8.05 & 5.17 \\
\hline & $2012 / 13$ & Rainfall (mm) & 21.84 & 13.46 & 42.42 & 45.72 & 28.7 & 43.94 & 47.5 & 8.14 \\
\hline & & $\operatorname{Max} \mathrm{T}\left({ }^{\circ} \mathrm{C}\right)$ & 29.01 & 30.21 & 27.99 & 30.11 & 31.03 & 28.43 & 24.32 & 22.61 \\
\hline & & $\operatorname{Min} \mathrm{T}\left({ }^{\circ} \mathrm{C}\right)$ & 12.43 & 14.62 & 15.41 & 16.81 & 15.5 & 14.58 & 9.12 & 3.86 \\
\hline \multirow[t]{6}{*}{ Taung } & 2011/12 & Rainfall (mm) & 3.05 & 36.07 & 71.37 & 7.87 & 40.89 & 12.45 & 5.08 & 0.51 \\
\hline & & $\operatorname{Max} \mathrm{T}\left({ }^{\circ} \mathrm{C}\right)$ & 31.05 & 33.28 & 32.8 & 36.12 & 32.87 & 32.96 & 28.02 & 27.65 \\
\hline & & $\operatorname{Min} T\left({ }^{\circ} \mathrm{C}\right)$ & 9.25 & 10.6 & 14.79 & 16.19 & 17.01 & 13.75 & 8.24 & 4.48 \\
\hline & $2012 / 13$ & Rainfall (mm) & 0.25 & 8.89 & 14.99 & 40.89 & 32.00 & 14.2 & 9.2 & 8.4 \\
\hline & & $\operatorname{Max} \mathrm{T}\left({ }^{\circ} \mathrm{C}\right)$ & 32.5 & 34.98 & 32.86 & 36.29 & 31.5 & 31.8 & 27.3 & 26.8 \\
\hline & & $\operatorname{Min} T\left({ }^{\circ} \mathrm{C}\right)$ & 10.74 & 14.27 & 15.71 & 17.83 & 17.7 & 15 & 9.4 & 6.2 \\
\hline \multirow[t]{6}{*}{ Rust } & 2011/12 & Rainfall (mm) & 23.37 & 49.79 & 47.24 & 19.3 & 6.35 & 27.94 & 6.6 & 0.25 \\
\hline & & $\operatorname{Max} T\left({ }^{\circ} \mathrm{C}\right)$ & 28.68 & 30.18 & 28.28 & 30.20 & 30.95 & 29.00 & 25.04 & 25.13 \\
\hline & & $\operatorname{Min} T\left({ }^{\circ} \mathrm{C}\right)$ & 11.71 & 14.91 & 17.00 & 15.34 & 17.21 & 14.37 & 9.34 & 6.58 \\
\hline & 2012/13 & Rainfall (mm) & 21.08 & 25.91 & 48.01 & 37.34 & 20.58 & 10.92 & 46.48 & 0 \\
\hline & & $\operatorname{Max} \mathrm{T}\left({ }^{\circ} \mathrm{C}\right)$ & 28.28 & 29.95 & 28.13 & 29.9 & 31.05 & 29.05 & 25.48 & 23.23 \\
\hline & & $\operatorname{Min} T\left({ }^{\circ} \mathrm{C}\right)$ & 12.82 & 14.76 & 16.14 & 17.38 & 16.28 & 14.67 & 10.17 & 4.68 \\
\hline
\end{tabular}

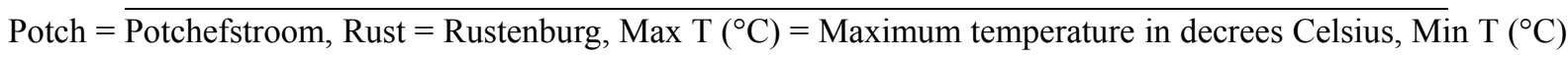
$=$ Minimum temperature in decrees Celsius, $\mathrm{mm}=$ millimetres.

\subsection{Experimental Design}

The experiment was established in 2010/11 planting season and data considered for experiment was collected during 2011/12 and 2012/13 planting seasons. The experimental design was factorial experiment laid out in 
random complete block design (RCBD) with three replicates. The statistical method was based on the previously published study by Blade et al. (1997). This technique allows accurate randomisation and analysis of variance for a multivariate design.

The experiment consisted of three cropping systems (monocropping, rotational and intercropping), three sites (Potchefstroom, Taung, and Rustenburg) and two levels of nitrogen fertilizer (urea) at each site, i.e., the amount of 0 and 20; 0 and 17; 0 and $23 \mathrm{~kg} \mathrm{~N} \mathrm{ha}^{-1}$ applied on maize plots at Potchefstroom, Rustenburg, and Taung respectively. Maize cultivar (PAN 6479) and cowpea (Bechuana white) were used as test crop.

\subsection{Chemical and Statistical Analysis}

Cowpea green leaves were harvested from the middle rows before flowering. Cowpea immature pods were also harvested from the middle rows during reproductive stage. Both green leaves and immature pods were oven dried at $65^{\circ} \mathrm{C}$ for three days. At maturity, seeds were harvested and oven dried for three days. All cowpea plant parts were sent to ARC-IIC for analysis of nitrogen content. The method used to determine the nitrogen content of cowpea plant parts was Kjeldahl digestion procedure (Kumar et al., 2014). The percent crude protein content was estimated using the relationship:

Crude protein $\%=\mathrm{N} \%$ x 6.25 (Ezeagu et al., 2002).

Analysis of variance was performed using GenStat $15^{\text {th }}$ edition (2012). Least significant difference (LSD) was used to separate means. A probability level of less than 0.05 was considered as significant statistically (Gomez \& Gomez, 1984).

\section{Results}

\subsection{Cowpea Leaf Protein}

Cropping system had significant effect on leaf protein content $(\mathrm{P}=0.046)$, as Figure 1 shows. Thus, the intercropped cowpea had significantly higher leaf protein content $(26.7 \%$ more $)$ than monocropped and rotational cowpea $(\mathrm{P}<0.05)$. Figure 1 also indicates that cowpea leaf protein content was significantly affected by site effect $(\mathrm{P}<0.001)$. In this case, cowpea planted at Taung and Potchefstroom had significantly higher leaf protein content (30.1 and 26.0\% more, respectively) than cowpea planted at Rustenburg $(\mathrm{P}<0.05)$.

Finally, cowpea leaf protein was significantly affected by the interaction of site and nitrogen and the interaction of site $\mathrm{x}$ season $(\mathrm{P}=0.024$ and $\mathrm{P}<0.001$, respectively) as indicated on Table 3 . According to Table 4 cowpea protein content was also significantly affected by the interaction of cropping system $\mathrm{x}$ site $\mathrm{x}$ nitrogen $(\mathrm{P}=0.012)$.

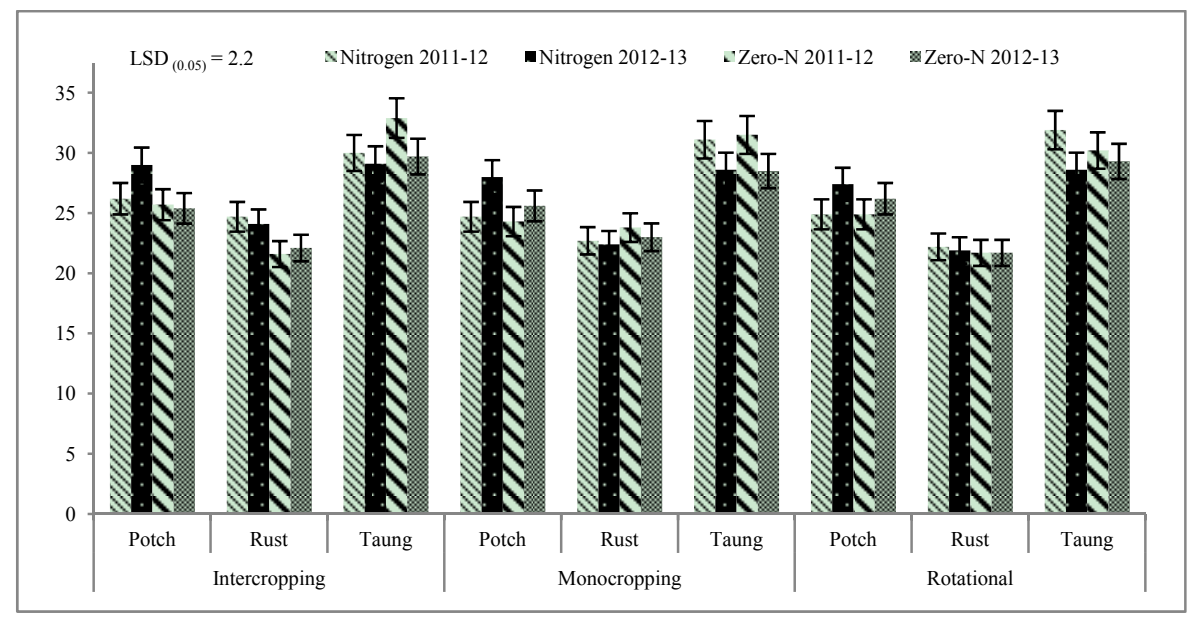

Figure 1. The interaction effects of cropping system, nitrogen fertilization and site on cowpea leaf protein content in percentages

Potch $=$ Potchefstroom, Rust $=$ Rustenburg, Zero-N $=$ Zero nitrogen fertilizer. 
Table 3. The interaction effects of site $\mathrm{x}$ season on cowpea leaf protein content. Potch $=$ Potchefstroom, Rust $=$ Rustenburg

\begin{tabular}{lll}
\hline \multirow{2}{*}{ Site } & \multicolumn{2}{c}{ Season } \\
\cline { 2 - 3 } & $2011 / 12$ & $2012 / 13$ \\
\hline Potch & 25.1 & 27.0 \\
Rust & 25.8 & 22.5 \\
Taung & 31.3 & 29.0 \\
LSD $_{(0.05)}$ & 0.90 & \\
\hline
\end{tabular}

Potch $=$ Potchefstroom, Rust $=$ Rustenburg, $\mathrm{N}$ - fertilization $=$ nitrogen fertilization, Zero-N $=$ zero nitrogen fertilizer.

Table 4. The interaction effects of site $\mathrm{x}$ nitrogen $\mathrm{x}$ season on cowpea leaf protein content.

\begin{tabular}{llllll}
\hline \multirow{2}{*}{ Site } & \multicolumn{2}{c}{ N-fertilization } & & \multicolumn{2}{c}{ Zero N } \\
\cline { 2 - 3 } \cline { 5 - 6 } & $2011 / 12$ & $2012 / 13$ & & $2011 / 12$ & $2012 / 13$ \\
\hline Potch & 25.2 & 28.2 & & 25.0 & 25.8 \\
Rust & 23.2 & 22.8 & & 22.4 & 22.3 \\
Taung & 31.0 & 28.8 & & 31.5 & 29.2 \\
$\operatorname{LSD}_{(0.05)}$ & 1.28 & & & &
\end{tabular}

Potch $=$ Potchefstroom, Rust $=$ Rustenburg, $\mathrm{N}$ - fertilization $=$ nitrogen fertilization, Zero-N $=$ zero nitrogen fertilizer.

\subsection{Cowpea Immature Pod Protein}

Cowpea immature pod protein was significantly affected by site effect $(\mathrm{P}=0.033)$ as indicated in Figure 2 . Cowpea planted at Rustenburg and Taung had significantly higher immature pod protein content (19.5 and 19.3

$\%$ more, respectively) than cowpea planted at Potchefstroom $(\mathrm{P}<0.05)$. Nitrogen fertilizer application had significant effect on cowpea immature pod protein $(\mathrm{P}=0.024)$. Cowpea applied with nitrogen fertilizer had significantly higher immature pod protein content $(19.5 \%$ more) than cowpea without nitrogen fertilizer application ( $\mathrm{P}<0.05)$. Cowpea planted during $2012 / 13$ planting season had significantly higher immature pod protein content $(20.1 \%$ more) than cowpea planted during $2011 / 12$ planting season $(\mathrm{P}<0.05)$. Finally, cowpea immature pod protein was significantly affected by the interaction of site $\mathrm{x}$ season $(\mathrm{P}<0.001)$ as indicated in Table 5.

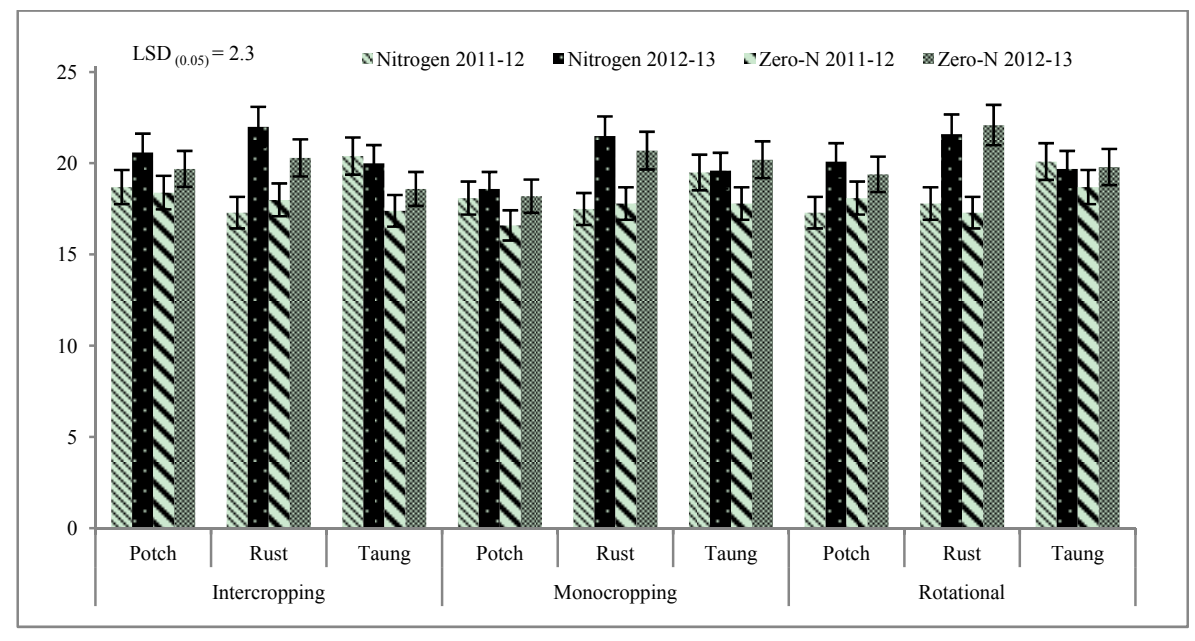

Figure 2. The interaction effects of cropping system, nitrogen fertilization and site on cowpea immature pod protein content in percentages

Potch $=$ Potchefstroom, Rust $=$ Rustenburg, Zero-N $=$ Zero nitrogen fertilizer. 
Table 5. The interaction effects of site $\mathrm{x}$ season on cowpea immature pods protein content. Potch $=$ Potchefstroom, Rust $=$ Rustenburg.

\begin{tabular}{lll}
\hline \multirow{2}{*}{ Site } & \multicolumn{2}{c}{ Season } \\
\cline { 2 - 3 } & $2011 / 12$ & $2012 / 13$ \\
\hline Potch & 17.9 & 19.4 \\
Rust & 17.6 & 21.4 \\
Taung & 19.0 & 19.7 \\
LSD $_{(0.05)}$ & 0.95 & \\
\hline
\end{tabular}

\subsection{Cowpea Seed Protein}

As seen in Figure 3, cowpea seed protein content was significantly affected by site effect $(\mathrm{P}<0.001)$. Thereby, cowpea planted at Rustenburg and Potchefstroom had significantly higher seed protein content $(23.8$ and $23.3 \%$ more, respectively) than cowpea planted at Taung $(\mathrm{P}<0.05)$. Moreover, Figure 3 also shows that cowpea seed protein content was significantly affected by the interaction of site $\mathrm{x}$ season and the interaction of site $\mathrm{x}$ nitrogen $\mathrm{x}$ season $(\mathrm{P}<0.001$ and $\mathrm{P}=0.034$, respectively) (Tables 6 and 7 ). Last, cowpea seed protein content was also significantly affected by the interaction of cropping system $\mathrm{x}$ site $\mathrm{x}$ nitrogen $\mathrm{x}$ season $(\mathrm{P}=0.033)$, as Figure 3 indicates.

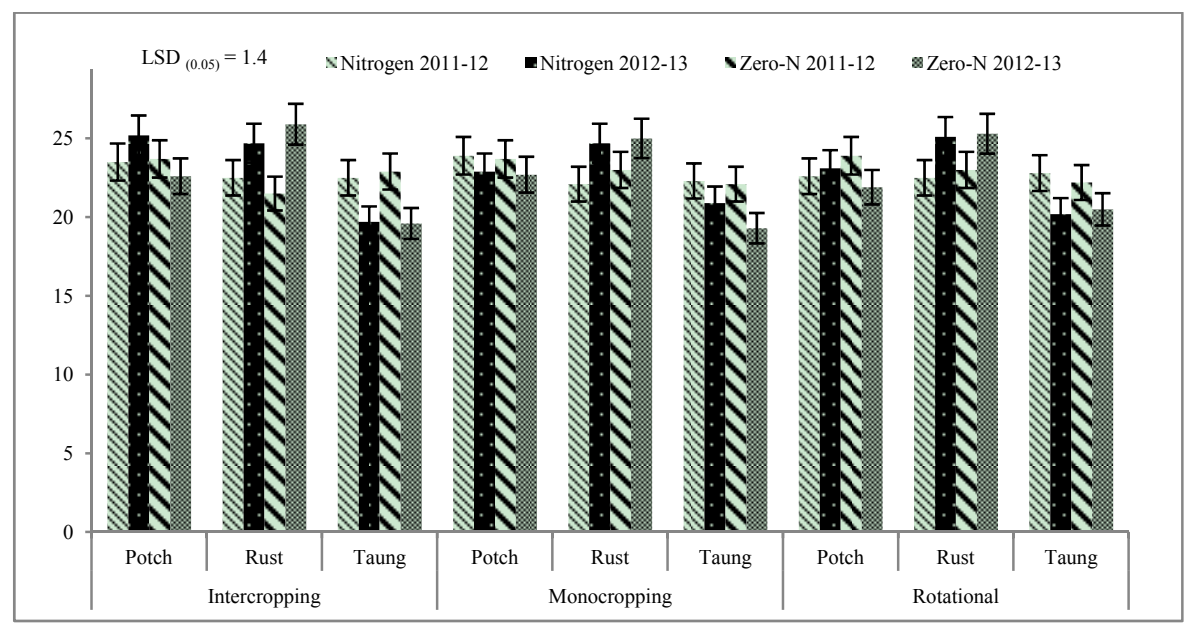

Figure 3. The interaction effects of cropping system, nitrogen fertilization and site on cowpea seed protein content in percentages

Potch $=$ Potchefstroom, Rust $=$ Rustenburg, Zero-N $=$ Zero nitrogen fertilizer

Table 6 . The interaction effects of site $\mathrm{x}$ season on cowpea seeds protein content

\begin{tabular}{lll}
\hline \multirow{2}{*}{ Site } & \multicolumn{2}{c}{ Season } \\
\cline { 2 - 3 } & $2011 / 12$ & $2012 / 13$ \\
\hline Potch & 23.5 & 23.0 \\
Rust & 22.4 & 25.1 \\
Taung & 22.5 & 20.0 \\
LSD $_{(0.05)}$ & 0.59 & \\
\hline
\end{tabular}

Potch $=$ Potchefstroom, Rust $=$ Rustenburg. 
Table 7. The interaction effects of site $\mathrm{x}$ nitrogen $\mathrm{x}$ season on cowpea seeds protein content. Potch $=$ Potchefstroom, Rust $=$ Rustenburg, $\mathrm{N}$ - fertilization $=$ nitrogen fertilization, Zero-N $=$ zero nitrogen fertilizer.

\begin{tabular}{llllll}
\hline \multirow{2}{*}{ Site } & \multicolumn{2}{c}{ N-fertilization } & & \multicolumn{2}{c}{ Zero N } \\
\cline { 2 - 3 } \cline { 5 - 6 } & $2011 / 12$ & $2012 / 13$ & & $2011 / 12$ & $2012 / 13$ \\
\hline Potch & 23.3 & 23.7 & & 23.8 & 22.4 \\
Rust & 22.4 & 24.9 & & 22.5 & 25.4 \\
Taung & 22.5 & 20.3 & & 22.4 & 19.8 \\
LSD $_{(0.05)}$ & 0.83 & & & \\
\hline
\end{tabular}

\subsection{Correlation between Soil $\mathrm{N}-\mathrm{NO}_{3}$ and Cowpea Protein Content}

The statistical analysis, i.e., the correlation study between soil $\mathrm{N}-\mathrm{NO}_{3}$ and cowpea protein content, are presented in Figure 4. According to Figure 4.1, the correlation between soil N-NO 3 and leaf protein content was weak $\left(\mathrm{R}^{2}\right.$ $=0.28)$ in 2011/12 planting season and become very weak $\left(R^{2}=0.03\right)$ in 2012/13 planting season. Moreover, the correlation between soil $\mathrm{N}_{-} \mathrm{NO}_{3}$ and immature pod protein (Figure 4.2) during 2011/12 planting season was weak $\mathrm{R}^{2}=0.24$ as was the case in $2012 / 13\left(\mathrm{R}^{2}=0.07\right)$. Finally, the correlation between soil N-NO 3 and seed protein as indicated in Figure 4.3, was very weak $\left(\mathrm{R}^{2}=0.04\right)$ in 2011/12 planting season and during 2012/13 season it was also weak $\left(\mathrm{R}^{2}=0.17\right)$
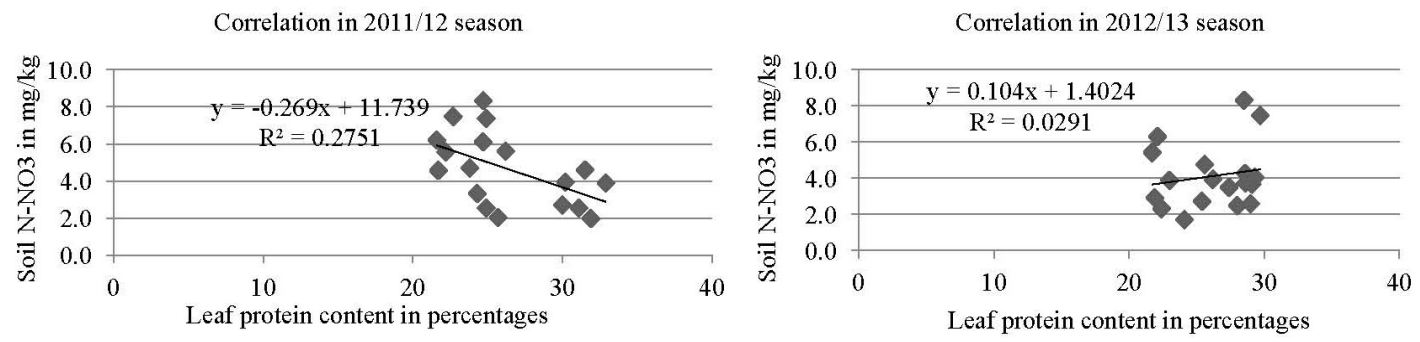

(1) Correlation between soil nitrate and leaf protein content in during two planting seasons
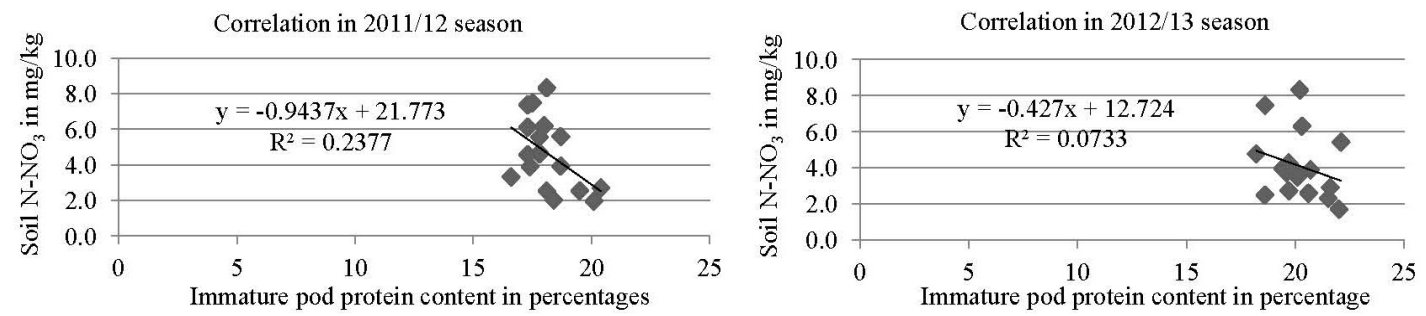

(2) Correlation between soil nitrate and immature pod protein content during two planting seasons
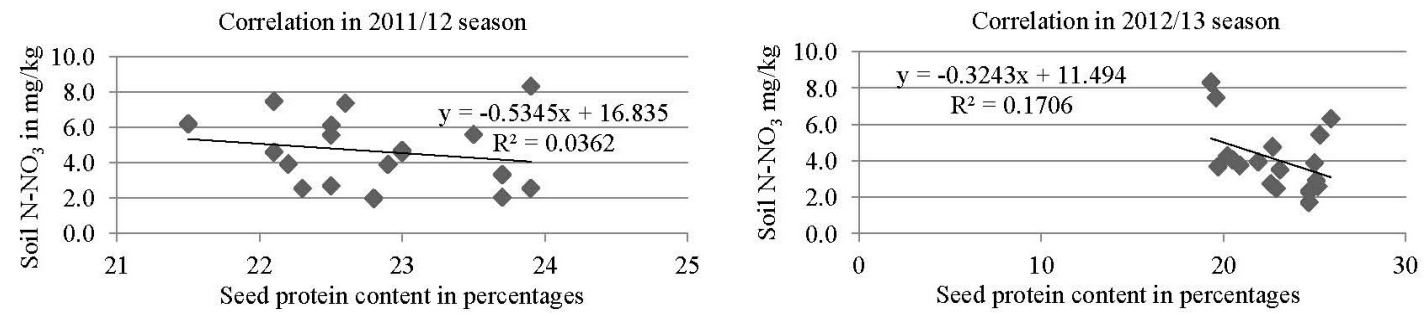

(3) Correlation between soil nitrate and seed protein content during two planting seasons

Figure 4. The correlation between Soil nitrate and cowpea protein content in different plant parts during two seasons 


\section{Discussion}

\subsection{Cowpea Leaf Protein}

The higher leaf protein of cowpea planted on intercropping system may be attributed to the shading by maize plants (Figure 1). According to Vu et al. (2006) UV-B and UV-Bseu radiations of 1.36 and 1.83, respectively, can lead to decrease in soluble protein in leaf extract of legumes when exposed to such amount of radiation. This possibly affected photosynthesis, quality of photosynthates and protein partitioning.

The results confirm the statements by Musa et al. (2011) that intercropping increases the dry matter, ash, protein and fiber content of cowpea. Eskandari (2012) also found that the forage quality of cowpea and mungbean in terms of crude protein content was significantly affected by cropping systems. This implies that intercropping plays positive role in crude protein content of cowpea leaves during vegetative stage of crops due to shading effects by maize.

\subsection{Cowpea Immature Pods Protein}

The protein content of immature pods in this study was lower as compared to protein content of immature leaves and seeds during harvest maturity (Figure 2). The hypothesis was that, immature pods protein will be higher than seeds during harvest as stated by Mlynekova and Ceresnakova (2013) that crude protein decline with increasing crop maturity. That findings contradicted with the findings of this study, where seed harvested at maturity had more protein content than immature pods harvested during reproductive stage and this contributed to the significant of this study towards cowpea protein improvement.

The contribution of nitrogen fertilizer on cowpea immature pods confirms the statements by Hasan et al. (2010) that, there was a progressive increase in the protein content of cowpea forage being influenced by the increasing level of nitrogen fertilizer. Ayub et al. (2010) found that the crude protein contents of cluster bean were significantly increased with increasing nitrogen rates. The maximum crude protein contents were obtained when nitrogen was applied at $45 \mathrm{~kg} \mathrm{ha}^{-1}$. It was further reported that the higher crude protein at higher nitrogen was mainly due to structural role of nitrogen in building up amino acid (Chintala et al., 2012a, 2012b).

Ayan et al. (2012) reported that at one location, average crude protein was different between years. The similar results were also observed in this study, where immature pod protein was higher in 2012/13 than 2011/12 planting season. This may have been attributed to different climatic conditions such as temperature and rainfall across the seasons.

\subsection{Cowpea Seed Protein}

The difference of seed protein content in different locations may be attributed to different soil types and weather conditions (Figure 3). The study by Lauriault et al. (2011) indicated that protein content of cowpea did not differ among soil types of sites. In the present study, the significant finding is that, cowpea crude protein differs by site due to different in soil fertility and structure. Soil with high amount of nitrogen tends to have more cowpea crude protein content. The high leaf protein at Taung and Potchefstroom was due to soil nitrogen, which was 2.83 and 3.10 respectively at those locations. Lim (2012) reported that cowpea performs best on well drained sandy loam or sandy soil where $\mathrm{pH}$ is in the range of 5.5 to 6.5. Also, Ayan et al. (2012) found that location and all the interactions in their study showed significant effect on cowpea crude protein.

The interaction effect of cropping system, site and nitrogen fertilizer on cowpea leaf and seed protein content contributed significantly towards cowpea quality improvement, since during previous studies, such interaction effects on cowpea protein content were not revealed. As examples of previous research studies, Mukhtar et al. (2010) reported that the comparison of cowpea between two seasons, nitrogen content was more in the dry season than in the rainy season; protein content of the leaves was found to be higher in the dry season than in the rainy season. Wilson et al. (2014) reported the interaction of year x nitrogen to be significant on protein content of soybean cultivar; thus, the protein concentration decreased linearly over years. Meanwhile, Ayan et al. (2012) reported that no differences were found in cowpea crude protein among cultivars and years. Musa et al. (2011) reported that, intercropping and nitrogen fertilization significantly increased protein digestibility of seeds compared to untreated plants for two seasons.

\subsection{Correlation between Soil $\mathrm{N}-\mathrm{NO}_{3}$ and Cowpea Protein Content}

In this study, the correlation between soil $\mathrm{N}-\mathrm{NO}_{3}$ and cowpea protein content was weak in both planting season (Figure 4). This may have been attributed to the fact that, cowpea is able to fix soil nitrogen and application of nitrogen fertilizer and the available of soil nitrogen will not affect $\mathrm{N}$ content in cowpea tissues. This indicates that, cowpea is not capable of absorbing soil nitrates as compared to cereal crops, which are good at absorbing 
residual nitrate (Gaskell \& Smith, 2007). Cowpea in addition to absorbing residual N, also add additional N through fixation of atmospheric $\mathrm{N}$.

\section{Conclusions}

The study was conducted to determine whether site, cropping system and nitrogen fertilizer application and the interaction of these factors have effect on cowpea protein content. In this study, intercropping played a role on cowpea leaf protein content. Intercropping has ability to increase the crude protein content in cowpea immature leaves. Treating cowpea with nitrogen fertilizer contributed to higher protein content of immature pods. Crop rotation has no role on protein content of cowpea plant parts. The interaction of cropping system $\mathrm{x}$ site $\mathrm{x}$ nitrogen played a vital role in this study since it affected cowpea leaf protein and seed protein content. This implies that, the protein content of cowpea differs based on different sites due to different soil types and climatic conditions. The leaves and seeds should be treated as the best sources of crude protein for human and animal consumption, due to high percentage of protein in those plant parts. The correlation between soil nitrate and cowpea protein content is weak. Future studies should investigate the possible effect of sequential harvesting on protein content in different seed parts and a correlation between these systems with planting dates.

\section{References}

Ali, S., \& Mohammad, H. S. (2012). Forage yield and quality in intercropping of forage corn with different cultivars of berseem clover in different levels of nitrogen fertilizer. Journal of Food, Agriculture and Environment, 10(1), 602-604.

Ayan, I., Mut, H., Basaran, U., Acar, Z., \& Asci, O. O. (2012). Forage potential of cowpea (Vigna unguiculata L. Walp). Turkish Journal of Field Crops, 17(2), 135-138.

Ayub, M., Khalid, M., Rariq, M., Nadeem, M. A., \& Naeem, M. (2010). Effect of different seeding densities and nitrogen levels on growth, forage yield and quality attributes of cluster bean (Cyamoposis tetragonoloba Tuab.). Journal of Agricultural Technology, 7(5), 1409-1416.

Blade, S. F., Shetty, S. V. R., Terao, T., \& Singh, B. B. (1997). Recent developments in cowpea cropping systems research. In B. B. Singh, D. R. Mohan Raj, K. E. Dashiell, \& L. E. N. Jackai (Eds.), Advances in Cowpea Research. International Institute of Tropical Agriculture and Japan International Research Center for Agricultural Sciences.

Botha, A. D. P., Snyman, H. G., Hahne, H. C. H., Prinsloo, A. L., Steenkamp, C. J., \& Duplessis, D. P. (1968). Eienskappe van die gronde van die navorsings institute vir Tabak. Tegniese Mededeling 74. Rustenburg: Department van Landbou-Tegniese Dienste.

Chintala, R., McDonald, L. M., \& Bryan, W. B. (2012). Effect of soil water and nutrients on productivity of Kentucky bluegrass systems in acidic soils. Journal of Plant Nutrition, 35, 288-303. http://dx.doi.org/10.1080/01904167.2012.636131

Chintala, R., McDonald, L. M., \& Bryan, W. B. (2012). Optimization of water potential and nutrient levels for Kentucky bluegrass-white clover mixture on acidic soils. Biotechnology, Agronomy, Society and Environment, 16, 167-177.

Cruz, F. J. R., De Almeida, H. J., \& Dos Santos, D. M. M. (2014). Growth, nutritional status and nitrogen metabolism in Vigna unguiculata (L.) Walp is affected by aluminium. Australian Journal of Crop Science, $8(7), 1132-1139$.

Dugje, I. Y., Omoigui, L. O., Ekelene, F., Kamara, A. Y., \& Ajeigbe, H. (2009). Farmers guide to cowpea production in West Africa. IITA, Ibadan, Nigeria.

Ehlers, J. D., \& Hall, A. E. (1997). Cowpea (Vigna unguiculata L. Walp.). Field Crops Research, 53, $187-204$. http://dx.doi.org/10.1016/S0378-4290(97)00031-2

Elias, L. G., Colindres, R., \& Bressani, R. (2006). The nutritive value of eight varieties of cowpea (Vigna sinensis). Journal of Food Science, 29(1), 118-122. http://dx.doi.org/10.1111/j.1365-2621.1964.tb01705.x

El Naim, A., Jabereldah, A. A., Ahmed, S. E., Ismaeil, F. M., \& Ibraim, E. A. (2012). Determination of suitable variety and plants per stand of cowpea (Vigna unguiculata L. Walp) in the sandy soil, Sudan. Advances in Life Science, 2(1), 1-5. http://dx.doi.org/10.5923/j.als.20120201.01

Eskandari, H. (2012). Intercropping of maize (Zea mays) with cowpea (Vigna sinensis) and mungbean (Vigna radiata): Effect of complementarity of intercrop components on resource consumption, dry matter production and legumes forage quality. Journal of Basic and Applied Scientific Research, 2(1), 355-360. 
Ezeagu, I. E., Petzke, J. K., Metges, C. C., Akinsoyinu, A. O., \& Ologhobo, A. D. (2002). Seed protein contents and nitrogen to protein conversion factors for some uncultivated tropical plant seeds. Food Chemistry Journal, 78, 105-109. http://dx.doi.org/10.1016/S0308-8146(02)00105-X

Gaskell, M., \& Smith, R. (2007). Nitrogen sources for organic vegetable crops. Hort Technology, 17(4), 431-441.

Gomez, K. A., \& Gomez, A. A. (1984). Statistical Procedures for Agricultural Research. John Wiley and Sons. New York.

Hamdollah, E. (2012). Yield and quality of forage produced in intercropping of maize (Zea mays L.) with and mungbean (Vigna radiate L.) as double cropped. Journal of Basic and Applied Scientific Research, 2(1), 93-97.

Hasan, M. R., Akbar, M. A., Khandaker, Z. A., \& Rahman, M. M. (2010). Effect of nitrogen fertilizer on yield contributing character, biomass yield and nutritive value of cowpea forage. Bangladesh Journal of Animal Science, 39(1\&2), 83-88.

Kamai, N., Gworgwor, N. A., \& Wabekwa, J. W. (2014). Varietal trial and physiological components determining yield differences among cowpea varieties in semiarid zone of Nigeria. Hindawi Publish corporation. ISRN Agronomy, 2014, 7. http://dx.doi.org/10.1155/2014/925450

Kumar, S., Nakajima, T., Mbonimpa, E. G., Gautam, S., Somireddy, U. R., Kadono, A., ... Fausey, N. (2014). Long-term tillage and drainage influences on soil organic carbon dynamics, aggregate stability, and carbon yield. Soil Science and Plant Nutrition, 60(1), 108-118. http://dx.doi.org/10.1080/00380768.2013.878643

Lauriault, L. M., Angadi, S. V., \& Marsalis, M. A. (2011). Soil type affected cowpea forage nutritive value. Forage and Grazinglands. http://dx.doi.org/10.1094/FG-2011-0126-01-BR

Lim, T. K. (2012). Edible medicinal and non-medicinal plants (pp. 371-380). Netherlands: Springer. http://dx.doi.org/10.1007/978-90-481-8661-7_16

Macvicar, C. N., De Villiers, J. M., Loxton, R. F., Verster, E., Lambrechts, J. J. N., Merryweather, F. R., ... Harmse, H. J. (1977). Soil classification. A binomial system for South Africa. Science Bull., 390, ARC-Institute for Soil Climate and Water, Pretoria.

Mlynekova, Z., \& Ceresnakova, Z. (2013). Degradation of starch and crude protein in dent and dent x flint maize hybrids in different stages of maturity. Slovak Journal of Animal Science, 46(2), 61-67.

Mukhtar, F. B., Mohammed, M., \& Ajiegbe, H. A. (2009). Effect of farmyard manure on senescence, nitrogen and protein levels in leaves and grains of some cowpea varieties. Bayero Journal of Pure and Applied Sciences, 3(1), 96-99.

Musa, E. M., Elsheikh, E. A. E., Ahmed, I. A. M., \& Babiker, E. E. (2011). Effect of intercropping, Bradyrhizobium inoculation and N, P fertilizers on yields, physical and chemical quality of cowpea seeds. Frontiers of Agriculture in China, 5(4), 543-557. http://dx.doi.org/10.1007/s11703-011-1147-6

Mwanarusi, S., Itulya, F. M., Aguyoh, J. N., \& Mshenga, P. M. (2010). Yields and profitability of a dual-purpose sole cowpea and cowpea-maize intercrop as influenced by cowpea leaf harvesting frequency. ARPN Journal of Agricultural and Biological Science, 5(5), 65-71.

Ogunkanmi, L. A., Taiwo, A., Mogaji, O. L., Awobodede, A., Eziashi, E. E., \& Ogundipe, O. T. (2006). Assessment of genetic diversity among cultivated cowpea (Vigna unguiculata L. Walp.) cultivars from a range of localities across West Africa using agronomic traits. Journal Scientific Research and Development, $10,111-118$

Pule-Meulenberg, F., Belane, A. K., Krasova-Wadet, T., \& Dakora, F. D. (2010). Symbiotic functioning and bradyrhizobial biodiversity of cowpea (Vigna unguiculata L. Walp.) in Africa. BMC Microbiology.

Santos, C. A. F., \& Boiteux, L. S. (2013). Breeding biofortified cowpea lines for semi-arid tropical areas by combining higher seed protein and mineral levels. Genetic and Molecular Research, 12(4), 6782-6789. http://dx.doi.org/10.4238/2013.December.16.4

Shi, Y., Ma, Y., Ma, W., Liang, C., Zhao, X., Fang, J., \& He, J. (2013). Large scale patterns of forage yield and quality across Chinese grasslands. Chinese Science Bulletin, 58(10), 1187-1199. http://dx.doi.org/10.1007/s11434-012-5493-4

Singh, J., \& Basu, P. S. (2012). Non-nutritive bioactive compounds in pulses and their impact on human health: An overview. Food and Nutrition Science, 3(12), 1664-1672. http://dx.doi.org/10.4236/fns.2012.312218 
Soil Survey Staff. (1999). Keys to soil taxonomy (8th ed.). Poca-hontas Press Inc., Blacksburg. Virginia.

Timko, M. P., \& Singh, B. B. (2008). Cowpea, a multi-functional legume. Genomics of Tropical Crop Plants, 227-258. http://dx.doi.org/10.1007/978-0-387-71219-2_10

Vadivel, V., \& Pugalenthi, M. (2010). Evaluation of nutritional value and protein quality of an under-utilized tribal food legume. Indian Journal of Traditional Knowledge, 9(4), 791-797.

Vu, C. V., Allen, L. H., \& Garrard, L. A. (2006). Effect of supplemental UV-B radiation on primary photosynthetic carboxylating enzymes and soluble proteins in leaves of $\mathrm{C}_{3}$ and $\mathrm{C}_{4}$ crop plants. International Journal of Plant Biology, 55, 11-16.

Wilson E. W., Rowntree, S. C., Suhre, J. J., Weidenbenner, N. H., Conley, S. P., Davis, V. M., ... Casteel, S. N. (2014). Genetic gain x management interactions in soybean: II. Nitrogen Utilization. Crop Science, 54, 340-348. http://dx.doi.org/10.2135/cropsci2013.05.0339

\section{Copyrights}

Copyright for this article is retained by the author(s), with first publication rights granted to the journal.

This is an open-access article distributed under the terms and conditions of the Creative Commons Attribution license (http://creativecommons.org/licenses/by/3.0/). 